\title{
Nanotoxicology: a perspective and discussion of whether or not in vitro testing is a valid alternative
}

\author{
Martin J. D. Clift • Peter Gehr • \\ Barbara Rothen-Rutishauser
}

Received: 18 February 2010/ Accepted: 5 May 2010/Published online: 25 May 2010

(C) Springer-Verlag 2010

\begin{abstract}
Despite the many proposed advantages related to nanotechnology, there are increasing concerns as to the potential adverse human health and environmental effects that the production of, and subsequent exposure to nanoparticles (NPs) might pose. In regard to human health, these concerns are founded upon the plethora of knowledge gained from research relating to the effects observed following exposure to environmental air pollution. It is known that increased exposure to environmental air pollution can cause reduced respiratory health, as well as exacerbate preexisting conditions such as cardiovascular disease and chronic obstructive pulmonary disease. Such disease states have also been associated with exposure to the NP component contained within environmental air pollution, raising concerns as to the effects of NP exposure. It is not only exposure to accidentally produced NPs however, which should be approached with caution. Over the past decades, NPs have been specifically engineered for a wide range of consumer, industrial and technological applications. Due to the inevitable exposure of NPs to humans, owing to their use in such applications, it is therefore imperative that an understanding of how NPs interact with the human body is gained. In vivo research poses a beneficial model for gaining immediate and direct knowledge of human exposure to such xenobiotics. This research outlook however, has numerous limitations. Increased research using in vitro models has therefore been performed, as these models provide an inexpensive and high-throughput alternative to
\end{abstract}

This article is published as part of Special Issue on Nanotoxicology.

M. J. D. Clift $(\bowtie)$ · P. Gehr · B. Rothen-Rutishauser

Institute of Anatomy, Division of Histology,

University of Bern, 3000 Bern 9, Switzerland

e-mail: martin.clift@ana.unibe.ch in vivo research strategies. Despite such advantages, there are also various restrictions in regard to in vitro research. Therefore, the aim of this review, in addition to providing a short perspective upon the field of nanotoxicology, is to discuss (1) the advantages and disadvantages of in vitro research and (2) how in vitro research may provide essential information pertaining to the human health risks posed by NP exposure.

Keywords Nanotechnology - Nanoparticle . In vitro testing strategies - Human health - Toxicity . Nanotoxicology · Environmental air pollution . NP exposure

\section{Introduction}

Over the past twenty years, the increase in nanotoxicology research has been concomitant with the overwhelming increase in the level of nanotechnology-related products being produced (Maynard 2007). This new industrial revolution promises to provide an advantageous basis for numerous applications, including medicine, consumer products (such as cosmetics and sporting equipment), environmental remediation and information technology (Maynard 2007), and is proposed to have a net worth of $\$ 15$ billion by 2015 (Service 2004).

In order to realise these proposed benefits, heightened research has been performed over the past two decades in order to determine whether the potential benefits of nanotechnology could be recognised without any adverse impact upon human health, as well as, most recently, the environment. This has been aptly termed nanotoxicology. Based on the principles of toxicology (Timbrell 1999), nanotoxicology can be defined as 'the study of the effects 
of nanoparticles (NPs) (either accidentally produced or engineered) on living organisms' and described as a multidisciplinary science including material science, chemistry, physics and medicine (Donaldson et al. 2004). The field of nanotoxicology focuses upon gaining a thorough understanding of the relationship between properties such as particle size, surface area and reactivity, dose (concentration), material composition and the potential toxicity of NPs. In relation to this, it is also proposed that nanotoxicology will develop and implement 'nano-specific' protocols in order to investigate and gain the knowledge necessary in order to determine the potential toxicity of the plethora of different NPs. In addition to this, it is important to note that over the past decade, there has been increased confusion as to the definition of a NP. The International Organization for Standardization (ISO), has provided specific definitions in their recent document entitled "Nanotechnologies - Terminology and definitions for nanoobjects-Nanoparticle, nanofibre and nanoplate". For the basis of this review, the following definition for a NP; a nano-object [a material with one, two or three external dimensions in the nanoscale $(1-100 \mathrm{~nm})]$ with all three external dimensions in the nanoscale (ISO/TS: 27687: 2008); will be used.

The requirement for gaining an understanding of the potential adverse effects of NP exposure is, in part, based upon the known effects of exposure to environmental air pollution. It is well understood that the NP component contained within environmental air pollution, specifically particulate matter with a size of $10 \mu \mathrm{m}$ or less $\left(\mathrm{PM}_{10}\right)$, can increase the potential for humans to exhibit increased pulmonary diseases. However, due to the rapid advent of new, engineered NPs, as well as what is already known in regard to exposure to (accidentally produced) NPs within environmental air pollution, the need to understand the potential effects of exposure to these nano-sized materials requires efficient, effective and speedy assessment. This, of course, would be possible using in vitro testing strategies; however, the questions remains whether or not such testing strategies are enough to define what the exact effect would be in vivo. The aim of this review therefore in addition to providing a short perspective upon the field of nanotoxoicology is to discuss (1) the advantages and disadvantages of in vitro research and (2) how in vitro research may provide essential information pertaining to the human health risks posed by NP exposure.

\section{Nanotoxicology: a brief perspective}

Recently, the field of nanotoxicology has been described as a multi-interdisciplinary field, consisting of biologists (including toxicologists), chemists (including biochemists), physicists, mathematicians and epidemiologists (European Science Foundation (ESF) Report 2005). This, however, is not a new concept to the field. Since the first studies that showed NPs to induce a heightened adverse effect on biological systems compared to their larger sized counterparts at the same mass dose (Ferin et al. 1992; Oberdorster et al. 1992), the understanding that NPs require a multidisciplinary approach (i.e. biology, physics, chemistry and medicine) has been accepted. Due to the constant increase in the number, type and sensitivity of equipment being used to study NPs and their subsequent effects, this multiinterdisciplinary approach has been significantly improved in the past few years (Bouwmeester et al. 2010). A complete review of the history and current status of the field of nanotoxicology is beyond the remit of this overview. In order to obtain a clear understanding of the field up to the current moment, it is suggested that such publications as Oberdorster et al. (2005, 2007), Donaldson et al. (2006), Stone et al. (2009) and Knol et al. (2009) are considered. Briefly, however, concern surrounding the exposure of humans to NPs (mainly) derives from their small size and emanates from two independent findings that separately recognised that as particle size decreases, toxicity generally increases.

One of the initial studies to demonstrate the potentially harmful effects of exposure to NPs was by Ferin et al. (1992). In this study, rats were exposed, via inhalation, to both NP (21 nm diameter) and fine $(250 \mathrm{~nm}$ diameter) titanium dioxide $\left(\mathrm{TiO}_{2}\right)$ particles, as well as intratracheally instilled with $\mathrm{TiO}_{2}$ particles of various sizes $(12,21,230$ and $250 \mathrm{~nm}$ in diameter) over a period of 12 weeks. Examination of the effects of treatment with each particle size was then performed over a 70-week post-exposure period. It was demonstrated that $\mathrm{TiO}_{2} \mathrm{NPs}$ promoted an acute inflammatory response following both intratracheal instillation and sub-chronic inhalation techniques compared to the larger particles (230 and $250 \mathrm{~nm}$ ). The inflammation observed in exposure animals was subsequently found to reduce to control levels post-exposure (64 weeks), with a noted decrease (from peak levels) in the number of neutrophils present in the lung at this time. NPs were also found to remain within the lung longer (501 days) than fine particles (174 days). The prolonged retention of $\mathrm{TiO}_{2} \mathrm{NPs}$ in the lung was suggested to be an effect of the finding that at equivalent masses, NPs were able to translocate to the pulmonary interstitium more efficiently than the larger $\mathrm{TiO}_{2}$ particles. It was suggested that the translocation of NPs to the interstitium was due to the smaller particles (12 and $21 \mathrm{~nm}$ ) not being taken up by alveolar macrophages and undergoing clearance from the alveoli via uptake by alveolar type- 1 epithelial cells instead. In addition to this, it was found that an increased dose (increased number of particles and decreased particle 
size) promoted movement of particles within the pulmonary system. It was also observed that the number of particles present, particle size, delivered dose and the delivered dose rate also had an effect on the translocation process. Ferin et al. (1992) concluded that the observed inflammation was due to exposure of the NPs to the rat lung, impaired lung clearance and NP redistribution.

In a subsequent publication, these findings were supported by Oberdorster et al. (1992), who showed increased levels of inflammation to be present in the alveolar space of rats after instillation with $500 \mu \mathrm{g} \mathrm{TiO}_{2} \mathrm{NPs}(20 \mathrm{~nm})$ over $24 \mathrm{~h}$, compared to $\mathrm{TiO}_{2}$ fine particles $(250 \mathrm{~nm})$ at the same mass dose. It was also found, in comparison with Ferin et al. (1992), that NPs were able to enter the interstitium more readily than the larger $\mathrm{TiO}_{2}$ particles. Oberdorster et al. (1992) further suggested that the increased inflammatory response to acute NP exposure could not be explained fully by the movement of particles to the interstitium but could be related to the larger surface area of the particles and their interaction with alveolar macrophages and interstitial cells. Focusing on alveolar macrophages, it was noted that they were effective inhibitors of the inflammatory response to NPs due to the active uptake of these particles. The findings of both Ferin et al. (1992) and Oberdorster et al. (1992) prompted increased interest into the effects of NPs on the lung, as well as the possible health effects that exposure to NPs might pose to respiratory and cardiovascular functions ( $\mathrm{Li}$ et al. 1997, 1999) and why these effects are observed (Brown et al. 2001; Duffin et al. 2002, 2007; Stoeger et al. 2006).

In addition to these laboratory investigations, epidemiological studies conducted over the last two decades have shown a positive correlation between the level of particulate air pollution and increased adverse health effects (Dockery et al. 1993; Bremner et al. 1999; Braga et al. 2000), including increased pulmonary diseases (Choudhury 1997; Pope and Dockery 1999; Schwartz 2004), as well as a rise in the number of deaths from cardiovascular disease (Abbey et al. 1999; Aga et al. 2003; Zanobetti et al. 2003; Medina et al. 2004; Pope et al. 2009). Additional epidemiological studies have also reported a direct relationship between the exposure of NPs in air pollution and adverse health effects (Peters et al. 1997; Wichmann et al. 2000; Schulz et al. 2005). Specifically, Peters et al. (1997) reported that human respiratory ill health was associated with the number of ambient NPs inhaled. In this study, it was observed that twenty-seven non-smoking asthmatics, who resided within a highly polluted city in central Europe, had a significant decrease in the peak expiratory flow from their lungs over a 6-month period. It was concluded by Peters et al. (1997) that the adverse health effects observed following exposure to $\mathrm{PM}_{10}$ could be related to the size distribution of environmental air pollution and therefore supporting the theory originally stated by Seaton et al. (1995) that NPs could potentially drive toxicity in the lung.

Progress in the field of nanotoxicology has gained increased intensity since the aforementioned laboratorybased and epidemiological studies. A prime example of how the field has changed in the past decade is that it is now ingrained into researchers within the field that they must fully understand not only the cellular system they are using but also the NP suspensions they are using. In the studies by Ferin et al. (1992) and Oberdorster et al. (1992), the concept of particle characterisation was highlighted in their subsequent conclusions (i.e. particle size); however, understanding the fundamental particle characteristics was not so pertinent at that time compared to understanding the effects that the smaller particles had. Nowadays, however, it is well understood that particle size and, particularly, the surface area and reactivity (Brown et al. 2001; Duffin et al. 2002, 2007) are relative to their effects. It is no longer sufficient to simply suspend a dry or wet sample of NPs in the suspension vehicle of choice and then expose the chosen model (i.e. tissue or cell cultures) to these NPs. The concept for increased NP characterisation has been based upon reports showing that NPs can alter their characteristics, such as size, shape, zeta potential, surface area and reactivity, length, aspect ratio, chemical composition and surface attachments (such as the attachment of additional proteins to the surface of NPs when suspended in cell culture media containing serum proteins) when in different suspension media and after alternative preparation techniques. Thus, the particle suspension originally used and exposed to the experimental model is perhaps not the one interacting with the model, and so the hypothetical effect observed is possibly not relative to the original NP suspension used. Therefore, it is essential that information pertaining to the characteristics of NPs is obtained relative to the experimental set-up being used.

Although increased attention is now being given to the specific characteristics of the NPs being used, questions still arise concerning the specific exposure method employed relative to the potential exposure route for the cells used. For example, are suspension cultures suitable for assessing the effects of inhaled NPs, when exposure systems are available that can deposit defined doses of NPs at the air-liquid interface (Tippe et al. 2002; Diabaté et al. 2008; Lenz et al. 2009; Brandenberger et al. 2010). It may be argued, however, that suspension cultures are more beneficially used for the investigation of NPs that are for use in applications such as medicine and food, which could enter the human body via injection and ingestion (Knol et al. 2009). Additionally, suspension cultures would be beneficial for exposing cells of secondary target 
organs in the human body following their inhalation. Knowledge of the translocation of NPs following their inhalation (regarded as the primary exposure route of NPs) is in its infancy however, and the precise methods needed to understand this increasing area of nanotoxicology are yet to be confirmed (Knol et al. 2009). In addition to using realistic exposure systems, it is also pertinent to highlight the necessity to use realistic doses. Recent research into the toxicity of NPs (Ryman-Rasmussen et al. 2009) has shown detrimental effects of nano-objects over time; however, the concentrations used have been significantly higher than what any human would be exposed to. This parameter is of the upmost importance if the field of nanotoxicology is going to understand and provide a realistic knowledge base of NP effects to human health, which will help the production and use of nanotechnology applications within both an occupational and consumer setting.

Despite the need to measure the previously highlighted parameters and to maintain a realistic aspect to nanotoxicology research, the precise mechanism of NP toxicology is still not understood. Currently, the hypothesis that NPs induce adverse cellular effects via oxidative means (oxidative stress paradigm) (Donaldson et al. 2003) is used as a basis for many NP investigations. Recently, however, additional paradigms have been suggested for NPs, such as the fibre paradigm (Dörger et al. 2001; Donaldson and Tran 2004) and the theory of genotoxicity (Schins and Knaapen 2007). The fibre paradigm was recently and perhaps most notably highlighted in the paper by Poland et al. (2008), in which it was shown that multi-walled carbon nanotubes caused granulomas in the peritoneal cavity in vivo. This paradigm, however, can only be attributed to nanofibres and especially those relating to the specific characteristics of HARN (high aspect ration nanoparticles) (Donaldson et al. 2006). Thus, the plethora of spherical NPs available cannot fit this paradigm. They may, however, in addition with the fibrous nano-objects fit into the theory of genotoxicity. This theory has been based upon numerous testing strategies using NPs $>100 \mathrm{~nm}$ in size, with a few actually based upon NPs $<100 \mathrm{~nm}$ and so requires increased, in-depth research to fully understand the ability for NPs to be genotoxic, mutagenic and potentially carcinogenic.

Due to the increased attention and funding opportunities provided for nanotoxicology research over the past 5-10 years, there has been an abundance of published studies claiming to be assessing the effects of NPs in relation to human health (Oberdorster et al. 2007). In the majority of these publications, there have been the advantages of numerous time points, NP types and doses as well as end-points measured. This has only been possible due to the use of an in vitro-based testing strategy.

\section{Nanotoxicology testing in vitro}

As highlighted earlier, the ability to perform such a magnitude of research, which is required in order to maintain an even balance of knowledge and understanding of the effects of NPs compared to the augmented production of NP-based products and applications, has been specifically due to the availability of in vitro testing strategies. Similarly, the European Union has promoted the use of in vitro testing strategies for this reason to investigate the effects of new cosmetics (European Cosmetics directive; 76/768/ EEC), suggesting specific cell types, such as the human promyelomonocytic cell U937 (a surrogate dendritic cell line) for use in exposure and toxicological analyses.

Although any experimental analysis can be performed with cells obtained from either in vivo experimentation (ex-vivo) as well as in vitro, it is pertinent to highlight the constant debate of the advantages and disadvantages of both in vitro and in vivo. Although in vivo (specifically mice and rat models, however, also considering research on hamster, guinea pig and monkey models) research is known to enable scientific research to observe almost 'firsthand' the effects of a substance as they would occur in a homosapian, in vitro models provide the possibility to investigate toxic effects on human cells extensively, which cannot be conducted in vivo (Rothen-Rutishauser et al. 2008a). Cultured human and animal cells can be better controlled and therefore yield more reproducible data than in vivo systems; however, they require a high standardisation to maximise reproducibility.

Commonly, nanotoxicology studies have used monocultures of cells that are specific to organs of the body. For example, epithelial cells are commonly used, as these form the basis for many of the natural barriers formed within the human body. Macrophage cells are used as a model to study the effects of NPs on the human immune system. Dendritic cells are also used, however, not as commonly as macrophages. This is interesting as dendritic cells would, arguably, provide a more beneficial model for NP-immune system interactions due to their natural role within the human body and its innate/adaptive immune systems. Additionally, specific cells such as $\mathrm{C} 3 \mathrm{~A}$ and $\mathrm{HepG} 2$ cells are also used for example for the liver, the PC12 cell line is used for analysis of NPs with the brain, whilst there are also numerous tumour cell lines that are used, such as mesothelioma cell lines (e.g. IST-Mes3/2P). In fact, there are many different cell lines used for every different organ of the human body. Table 1 provides an example of the most commonly used human cell lines used in studies concerning nanotoxicology.

Although monoculture systems provide the basis for high-throughput analysis for nanotoxicology, they do not represent a realistic model of how NPs will interact with a 
Table 1 Human cell culture models used in studies for nanotoxicity

\begin{tabular}{|c|c|}
\hline Primary cultures & References \\
\hline Monocyte-derived macrophages & (Waldman et al. 2007) \\
\hline Monocyte-derived dendritic cells & (Blank et al. 2007; Rothen-Rutishauser et al. 2007, 2005) \\
\hline \multicolumn{2}{|l|}{ Cell lines } \\
\hline \multicolumn{2}{|l|}{ Airway epithelial cells } \\
\hline Calu-3 & (Bivas-Benita et al. 2004; Grenha et al. 2007; Rotoli et al. 2008) \\
\hline 16HBE14o- & (Brzoska et al. 2004; Holder et al. 2008) \\
\hline BEAS-2B & (Herzog et al. 2007; Jang et al. 2006; Park et al. 2007; Veranth et al. 2007) \\
\hline \multicolumn{2}{|l|}{ Alveolar epithelial cells } \\
\hline A549 & (Duffin et al. 2007; Park et al. 2007; Stearns et al. 2001) \\
\hline $\begin{array}{l}\text { Immortalised human alveolar type } 2 \text { cells } \\
\text { with alveolar type } 1 \text { phenotype }\end{array}$ & (Kemp et al. 2008) \\
\hline \multicolumn{2}{|l|}{ Macrophages } \\
\hline THP-1 & (Chen et al. 2006; Ece et al. 2008; Goulaouic et al. 2008; Wottrich et al. 2004) \\
\hline \multicolumn{2}{|l|}{ Fibroblasts } \\
\hline MRC-9 & (Limbach et al. 2005) \\
\hline \multicolumn{2}{|l|}{ Mesothelial cells } \\
\hline MSTO-211H & (Kaiser et al. 2008; Wick et al. 2007) \\
\hline \multicolumn{2}{|l|}{$3 \mathrm{D}$ cultures } \\
\hline $3 \mathrm{D}$ aggregates of A549 cells & (Carterson et al. 2005) \\
\hline $\begin{array}{l}\text { Triple cell co-culture model (epithelial cells, macrophages, } \\
\text { dendritic cells) }\end{array}$ & (Rothen-Rutishauser et al. 2007, 2008a, b) \\
\hline
\end{tabular}

Adapted from Blank et al. (2009)
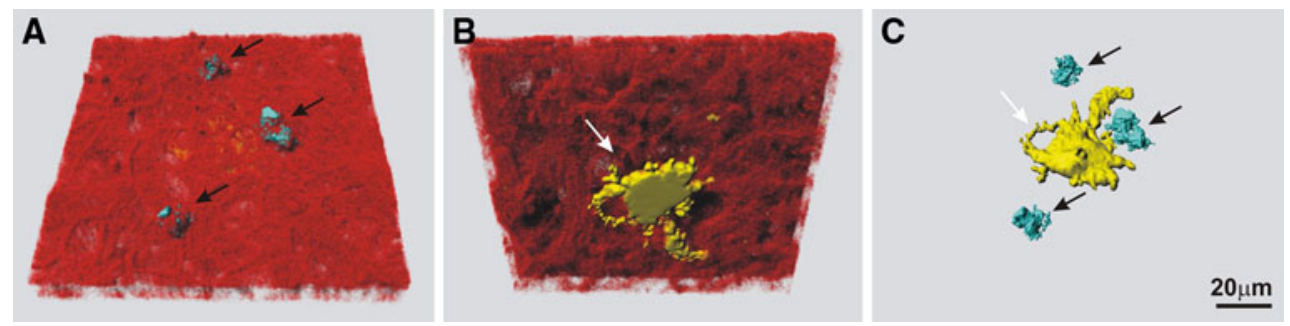

Fig. 1 Laser scanning microscopy images of the triple cell co-culture model established by Rothen-Rutishauser et al. (2005). Epithelial cells (red, volume rendering), human monocyte-derived macrophages (light blue, surface rendering; black arrows) and human monocyte-

specific organ of the body. Over the past 5 years, there have been increased efforts to establish more realistic models to study the toxic potential of NPs. An example of such an effort is the triple cell co-culture system composed of epithelial cell line (A549 or $16 \mathrm{HBE} 14 \mathrm{o}^{-}$), human monocyte-derived macrophages and dendritic cells that has been established, simulating the most important barrier functions of the epithelial airway by Rothen-Rutishauser et al. (2005). This model provides a clear basis for investigating the interaction of NPs with the lung (RothenRutishauser et al. 2005, 2008b) as well as at the air-liquid interface (Blank et al. 2006, 2007) (Fig. 1). It is also important to point out that in order to further mimic the situation in vivo, primary alveolar epithelial cells have derived dendritic cells (yellow, surface rendering; white arrow) are shown. The same data set is shown from top (a), from bottom (b) and without epithelial cells from top (c). Reproduced with permission from ALTEX (Rothen-Rutishauser et al. 2008b)

been harvested from human lung biopsies and employed in place of the epithelial cell lines commonly used in the triple cell co-culture model (Lehmann et al. 2010).

There are additional co-culture systems also available, such as the ones reported by Alfaro-Moreno et al. (2008) and Bhabra et al. (2009). The co-culture system of AlfaroMoreno et al. (2008) is in fact a 'quad-culture', containing epithelial, endothelial, macrophage and mast cells, whilst that of Bhabra et al. (2009) is a bi-culture of BeWo (placental) and human fibroblast cells. The latter study reported that cobalt-chromium $(\mathrm{CoCr})$ NPs can indirectly affect the homoeostasis of fibroblast cells despite being located behind a confluent layer of BeWo cells. It was suggested by Bhabra and colleagues that increased DNA damage 
observed in the human fibroblasts cells following $\mathrm{CoCr}$ NP exposure at $0.036-0.36 \mathrm{mg} \mathrm{cm}^{-2}$ was due to a novel mechanism in which purine nucleotides are transmitted through gap juntions, or hemichannels, in the BeWo cell layer. The study of Bhabra et al. (2009) highlights the advantages of using in vitro cell co-culture systems, as the indirect effects reported would not be observed using monoculture testing strategies, and so therefore without using such a co-culture system, incorrect information could be gathered concerning the potential risks of NPs. Despite these specific examples, numerous laboratories use such co-culture systems, whether bi-, triple- or quad-cultures. Additionally, laboratories also use the supernatant taken from exposed monocultures of one cell type and then use this to treat a different monoculture cell type. Although this is not an advantageous co-culture technique, it is a performed practice to gain an understanding of how NPs interact with different cells over time. It is, however, whilst there are suitable co-culture systems available that are cheap (up to 1/10th of the total cost of any in vivo testing strategy), efficient and easy to construct/use, perhaps a dated methodology.

One aspect emphasised by the model of RothenRutishauser et al. (2005) is that the architecture is specific to that as it is in the human lung (i.e. macrophages on the apical side, a layer of epithelial cells and dendritic cells on the basolateral side) (Fig. 1). This type of detail is absolutely essential as it provides a clear sign as to the interaction of NPs at the epithelial airway wall. Studies using co-culture cell systems have reported that they observe different reactions compared to monoculture analysis (Mueller et al. 2010; Lehmann et al. 2009); however, such reactions observed from a culture containing two, three or four different types of cells merely cultured in the same dish, (although providing data showing that NPs interact with different cells in an opposite manner to each cell monoculture) is not specific to that as it would occur in the human body. Thus, the architecture of the in vitro cell co-culture model in regard to the specific organ they represent is essential. Understanding how the organ works, taking time to prepare and perform series, upon series of baseline testing strategies, such as trans-epithelial electrical resistance (for epithelial layers), understanding the manner in which the cells interact with one another, the ratio of different cells to each other cell type in the co-culture, as well as if the cells remain viable in the co-culture are essential questions that must be thoroughly investigated prior to any form of nanotoxicology testing.

As previously highlighted in this review and the studies referenced, there are a number of different toxicological endpoints that researchers have used to assess the potential adverse effects that NPs may have on organs of the human body. These include numerous different biochemical- and molecular-based testing strategies, investigating the potential for NPs to cause cytotoxicity, inflammation, oxidative stress, cell proliferation and genotoxicity. It is also important to note that when assessing the potential toxicity of any form of NP, it is important to investigate how the particles enter the specific cells being examined and in which compartments they may be found within (or, which is also possible, if the NPs stay attached to the cell membrane). This is of great importance, as it has been shown that the uptake behaviour can influence the cellular response following NP exposure (Lovric et al. 2005; Unfried et al. 2007; Maysinger et al. 2007). As it is not possible to go into sufficient detail regarding the entry mechanisms of NPs into cells, it is suggested that Unfried et al. (2007), as well as Rothen-Rutishauser et al. (2007) and Muehlfeld et al. (2008a; b) which provide an extensive overview of these processes, are considered.

In addition to all of the previously mentioned parameters highlighted in this review that should be taken into consideration when assessing the potential toxicity of NPs (in relation to the specific experimental question), it is also vital that additional and appropriate (positive and negative) controls are used. These are of course relative to the specific methodology being employed. Although negative controls are easily identified (usually cell culture medium/ buffer only), determination of the correct positive control must be given more thought. For example, a low concentration of Triton X100 (such as 0.1 or $0.2 \%$ ) is able to provide a clear positive reaction in any lactate dehydrogenase (LDH) assay (either diagnostic kit, or laboratory protocol); however, this form of compound would not be useful when assessing the potential production of reactive oxygen species by NPs within cells. It is therefore pertinent that the reaction that the test is causing is debated and the most adequate and specific positive controls are used.

In addition, testing for false-positive and false-negative effects within many of the biochemical tests commonly used in NP toxicology testing is essential to obtain a clear answer as to their potential adverse effects upon cellularbased systems. These issues have previously been discussed in detail by Stone et al. (2009), and it is suggested that this in-depth review of in vitro toxicology testing strategies is considered. Examples of such false positive/ negative effects are, however, the ability for proteins to adsorb to the surface of NPs is realistic and can significantly affect the ability for NPs to interact with cellular systems. It is therefore also essential that the ability for proteins to adsorb to the surface of particles during toxicological tests is assessed [such as when using an enzymelinked immunosorbent assay (ELISA)]. This is also true of enzymes, such as LDH. It is known that this enzyme can also adsorb to the surface of NPs, masking their toxicity and thus providing a false-negative toxic result. As with 
protein adsorption, enzyme adsorption must also be investigated to correlate valid and representative toxicity data. Determination of these aspects is easily performed. Generally, the protocol consists of incubation of the NPs with the protein/enzyme for a period of time followed by the specific toxicological test (Clift et al. 2008). Any adsorption of the proteins or enzymes to the NPs is then apparent via a loss or increase in the specific protein/ enzyme being measured. Additionally, it is also necessary to determine the ability for the NPs used to interact with the assays in regard to the fluorescent dyes or formazans that are used. An example of this was reported by WorleKnirsch et al. (2006), where it was reported that carbon nanotubes interacted with the MTT formazan (tetrazolium salt) used and provided a false-negative toxicity. In addition to this, it is also pertinent that an assessment of the toxicity of the suspension media/buffer is performed. Increasingly, NPs are suspended in such buffers as Pluronic F127 and Tween80 in order to obtain a well-dispersed and characteristic NP suspension. If, however, a toxic response is observed following cellular exposure with NPs suspended in such buffers, it is essential that the toxicity of these buffers is known in order to assess the specific effects of the NPs only (Wick et al. 2007).

\section{Conclusion}

In summary, although the parameters highlighted in this review can be performed using either in vivo or in vitro models, due to the heightened level of control/baseline analysis needed, the advantages of in vitro research enable such experimental testing strategies beneficial to nanotoxicology. This, however, will not be sufficiently covered by only performing monoculture analyses. It is essential that co-culture systems mimicking the in vivo system are established and used for the specific organs that are in danger of interacting with NPs. These systems, however, will not be able to be completely definitive of the in vivo situation until further in vivo analyses are performed in order to confirm the findings of in vitro investigations. Thus, in conclusion, the future of nanotoxicology testing lays with in vitro research; however, increased acute and chronic in vivo research is necessary in order to fulfil this possibility and to subsequently reduce, refine and replace all animal experimentation.

\footnotetext{
Acknowledgments The authors would like to thank Christina Brandenberger, Andrea Lehmann, Loretta Mueller, Michael Gasser, David Raemy, Kirsten Dobson, Dagmar Kuhn, Andrea Stokes, Mohammed Ouanella and Barbara Tschirren for their vital input to the ongoing research of the laboratory of Prof. P. Gehr, as well as their assistance for the routine and helpful discussion from which this review has been partially based upon.
}

Conflict of interest statement The authors would like to report no conflict of interests. The authors are entirely responsible for the content and writing of the manuscript.

\section{References}

Abbey DE, Nishino N, McDonnell WF, Knutsen SF, Burchette RJ, Beeson WL, Yang JX (1999) Long-term inhalable particles and other air pollutants related to mortality in nonsmokers. Am J Respir Crit Care Med 159:373-382

Aga E, Samoili E, Touloumi G, Anderson HR, Cadum E, Forsber B, Goodman P, Goren A, Kotesovec F, Kriz B, Macarol-Hiti M, Medina S, Paldy A, Schindler C, Sunyer J, Tittanen P, Wojtyniak B, Zmiorou D, Schwartz J, Katsouyanni K (2003) Short-term effects of ambient particles on mortality in the elderly: results from 28 cities in the APHEA2 project. Eur Respir J 21:28s-33s

Alfaro-Moreno E, Nawrot TS, Vanaudenaerde BM, Hoylaerts MF, Vanoirbeek JA, Nemery B, Hoet PHM (2008) Co-cultures of multiple cell types mimic pulmonary cell communication in response to urban $\mathrm{PM}_{10}$. Eur Respir J 32:1184-1194

Bhabra G, Sood A, Fisher B, Cartwright L, Saunders M, Evans WH, Surprenant A, Lopez-Castejon G, Mann S, Davis SA, Hails LA, Ingham E, Verkade P, Lane J, Heesom K, Newson R, Case CP (2009) Nanoparticles can cause DNA damage across a cellular barrier. Nat Nanotech 4:876-883

Bivas-Benita M, Romeijn S, Junginger HE, Borchard G (2004) PLGA-PEI nanoparticles for gene delivery to pulmonary epithelium. Eur J Pharm Biopharm 58:1-6

Blank F, Rothen-Rutishauser BM, Schurch S, Gehr P (2006) An optimized in vitro model of the respiratory tract wall to study particle cell interactions. J Aerosol Med 19:392-405

Blank F, Rothen-Rutishauser B, Gehr P (2007) Dendritic cells and macrophages form a transepithelial network against foreign particulate antigens. Am J Respir Cell Mol Biol 36:669-677

Blank F, Gehr P, Rothen-Rutishauser B (2009) In vitro human lung cell culture models to study the toxic potential of nanoparticles. In: Sahu SC (ed) Nanotoxicity: From in vitro, in vivo models to health risks s. Wiley, Chichester, England, pp 379-395

Bouwmeester H, Lynch I, Marvin HJP, Dawson KA, Berges M, Braguer D, Byrne HJ, Casey A, Chambers G, Clift MJD, Elia G, Fernandes TF, Fjellsb $\varnothing$ LB, Hatto P, Juillerat L, Klein C, Kreyling WG, Nickel C, Riediker M, Stone V (2010) Minimal analytical characterisation of engineered nanomaterials needed for hazard assessment in biological matrices. Accepted by Nanotoxicology

Braga ALF, Zanobetti A, Schwartz J (2000) Do respiratory epidemics confound the association between air pollution and daily deaths? Eur Respir J 16:723-728

Brandenberger C, Rothen-Rutishauser B, Muhlfeld C, Schmid O, Ferron GA, Maier KL, Gehr P, Lenz AG (2010) Effects and uptake of gold nanoparticles deposited at the air-liquid interface of a human epithelial airway model. Toxicol appl Pharm 242:56-65

Bremner SA, Anderson HR, Atkinson RW, McMichael AJ, Strachan DP, Bland JM, Bower JS (1999) Short-term associations between outdoor air pollution and mortality in London 1992-4. Occ Environ Med 56:237-244

Brown DM, Wilson MR, MacNee W, Stone V, Donaldson K (2001) Size-dependent proinflammatory effects of ultrafine polystyrene particles: a role for surface area and oxidative stress in the enhanced activity of ultrafines. Toxciol Appl Pharm 175:191199 
Brzoska M, Langer K, Coester C, Loitsch S, Wagner TO, Mallinckrodt C (2004) Incorporation of biodegradable nanoparticles into human airway epithelium cells-in vitro study of the suitability as a vehicle for drug or gene delivery in pulmonary diseases. Biochem Biophys Res Commun 318:562-570

Carterson AJ, Honer zu BK, Ott CM, Clarke MS, Pierson DL, Vanderburg CR, Buchanan KL, Nickerson CA, Schurr MJ (2005) A549 lung epithelial cells grown as three-dimensional aggregates: alternative tissue culture model for Pseudomonas aeruginosa pathogenesis. Infect Immun 73:1129-1140

Chen HW, Su SF, Chien CT, Lin WH, Yu SL, Chou CC, Chen JJ, Yang PC (2006) Titanium dioxide nanoparticles induce emphysema-like lung injury in mice. FASEB J 20:2393-2395

Choudhury AH (1997) Associations between respiratory illness and $\mathrm{PM}_{10}$ air pollution. Arc Environ Health 52:113-117

Clift MJD, Brown DM, Rothen-Ruthishauser B, Duffin R, Donaldson K, Proudfoot L, Guy K, Stone V (2008) Comparing a panel of commercially available quantum dots and polystyrene nanoparticles with differing surface characteristics; an analysis of their uptake and toxicity in a murine macrophage cell line. Toxicol Appl Pharm 232:418-427

Diabaté S, Mülhopt S, Paur HR, Krug HF (2008) The response of a co-culture lung model to fine and ultrafine particles of incinerator fly ash at the air-liquid interface. Altern Lab Anim 36:285298

Dockery DW, Pope CA, Xu X, Spengler JD, Ware JH, Fay ME, Ferris BG, Speizer FE (1993) An association between air pollution and mortality in six U.S. cities. N Eng J Med 329:1753-1759

Donaldson K, Tran CL (2004) An introduction to the short-term toxicology of respirable industrial fibres. Mut Res/Fundamen Mol Mechan Mutagen 553:5-9

Donaldson K, Stone V, Borm PJ, Jimenez LA, Gilmour PS, Schins RPF, Knaapen AM, Rahman I, Faux SP, Brown DM, MacNee W (2003) Oxidative stress and calcium signalling in the adverse effects of environmental particles $\left(\mathrm{PM}_{10}\right)$. Free $\mathrm{Rad}$ Biol Med 34:1369-1382

Donaldson K, Stone V, Tran CL, Kreyling W, Borm PJA (2004) Nanotoxicology. Occ Environ Med 61:727-728

Donaldson K, Aitken R, Tran L, Stone V, Duffin R, Forrest G, Alexander A (2006) Carbon Nanotubes: a review of their properties in relation to pulmonary toxicology and workplace safety. Toxicol Sci 92:5-22

Dörger M, Münzing S, Allmeling A-M, Messmer K, Krombach F (2001) Differential Responses of Rat Alveolar and Peritoneal Macrophages to Man-Made Vitreous Fibers in Vitro. Environ Res 85:207-214

Duffin R, Tran CL, Clouter A, Brown DM, MacNee W, Stone V, Donaldson K (2002) The importance of surface area and specific reactivity in the acute pulmonary inflammatory response to particles. Ann Occ Hyg 46:242-245

Duffin R, Tran L, Brown D, Stone V, Donaldson K (2007) Proinflammogenic effects of low-toxicity and metal nanoparticles in vivo and in vitro: highlighting the role of particle surface area and surface reactivity. Inhal Toxicol 19:849-856

Ece GD, Shah LK, Devalapally H, Amiji MM, Carrier RL (2008) A model predicting delivery of saquinavir in nanoparticles to human monocyte/macrophage (Mo/Mac) cells. 2008. Biotechnol Bioeng 101:1072-1082

European Science Foundation (ESF) Report (2005) Nanomedicine; An ESF-European Medical Research Councils (EMRC) Forward Look Report

European Union Cosmetics directive 76/768/EEC; Amended document 2008

Ferin J, Oberdorster G, Penney DP (1992) Pulmonary retention of ultrafine and fine particles in rats. Am J Respir Cell Mol Biol $6: 535-542$
Goulaouic S, Foucaud L, Bennasroune A, Laval-Gilly P, Falla J (2008) Effect of polycyclic aromatic hydrocarbons and carbon black particles on pro-inflammatory cytokine secretion: impact of PAH coating onto particles. J Immunotoxicol 5:337-345

Grenha A, Grainger CI, Dailey LA, Seijo B, Martin GP, RemunanLopez C, Forbes B (2007) Chitosan nanoparticles are compatible with respiratory epithelial cells in vitro. Eur J Pharm Sci 31:73-84

Herzog E, Casey A, Lyng FM, Chambers G, Byrne HJ, Davoren M (2007) A new approach to the toxicity testing of carbon-based nanomaterials - the clonogenic assay. Toxicol Lett 174:49-60

Holder AL, Lucas D, Goth-Goldstein R, Koshland CP (2008) Cellular response to diesel exhaust particles strongly depends on the exposure method. Toxicol Sci 103:108-115

International Organization for Standardization (ISO) Technical Specification (ISO/TS) 27687:2008; Nanotechnologies-Terminology and definitions for nano-objects-Nanoparticle, nanofibre and nanoplate; First published 2008-08-15

Jang M, Ghio AJ, Cao G (2006) Exposure of BEAS-2B cells to secondary organic aerosol coated on magnetic nanoparticles. Chem Res Toxicol 19:1044-1050

Kaiser JP, Wick P, Manser P, Spohn P, Bruinink A (2008) Single walled carbon nanotubes (SWCNT) affect cell physiology and cell architecture. J Mater Sci Mater Med 19:1523-1527

Kemp SJ, Thorley AJ, Gorelik J, Seckl MJ, O'Hare MJ, Arcaro A, Korchev Y, Goldstraw P, Tetley TD (2008) Immortalisation of Human Alveolar Epithelial Cells to Investigate Nanoparticle Uptake. Am J Respir Cell Mol Biol 39:591-597

Knol AB, de Hartog JJ, Boogaard H, Slottje P, van der Sluijs JP, Lebret E, Cassee FR, Wardekker JA, Ayres JG, Borm PJ, Brunekreef B, Donaldson K, Forastiere F, Holgate ST, Kreyling WG, Nemery B, Pekkanen J, Stone V, WichmannH-E HoekG (2009) Expert elicitation on ultrafine particles: likelihood of health effects and causal pathways. Part Fibre Toxicol 6:19

Lehmann AD, Blank F, Baum O, Gehr P, Rothen-Rutishauser BM (2009) Diesel exhaust particles modulate the tight junction protein occluding in lung cells in vitro. Part Fibre Toxicol 6:26

Lehmann AD, Daum N, Lehr C-M, Bur M, Gehr P, RothenRutishauser B (2010) An in vitro triple cell co-culture model with primary cells mimicking the human alveolar epithelial barrier. Submitted to J Roy Soc Inter

Lenz AG, Karg E, Lentner B, Dittrich V, Brandenberger C, Rothen-Rutishauser B, Schulz H, Ferron GA, Schmid O (2009) A dose-controlled system for air-liquid interface cell exposure and application to zinc oxide nanoparticles. Part Fibre Toxciol 6:32

Li XY, Gilmour PS, Donaldson K, MacNee W (1997) In Vivo and In Vitro proinflammatory effects of particulate air pollution $\left(\mathrm{PM}_{10}\right)$. Environ Health Perspec 105:1279-1283

Li XY, Brown DM, Smith S, MacNee W, Donaldson K (1999) Shortterm inflammatory responses following intratracheal instillation of fine and ultrafine carbon black in rats. Inhal Toxicol 11:709731

Limbach LK, Li Y, Grass RN, Brunner TJ, Hintermann MA, Muller M, Gunther D, Stark WJ (2005) Oxide nanoparticle uptake in human lung fibroblasts: effects of particle size, agglomeration, and diffusion at low concentrations. Environ Sci Technol 39:9370-9376

Lovric J, Bazzi HS, Cuie Y, Fortin GRA, Winnik FM, Maysinger D (2005) Differences in subcellular distribution and toxicity of green and red emitting CdTe quantum dots. J Mol Med 83:377385

Maynard AD (2007) Nanotechnology: the next big thing, or much ado about nothing? Ann Occ Hyg 51:1-12

Maysinger D, Lovric J, Eisenberg A, Savic R (2007) Fate of micelles and quantum dots in cells. Eur J Pharm Biopharm 65:270-281 
Medina S, Plasencia A, Ballester F, Mucke HG, Schwartz J (2004) Apheis: public health impact of PM10 in 19 European cities. J Epidemiol Com Health 58:831-836

Mueller L, Riediker M, Wick P, Mohr M, Gehr P, Rothen-Rutishauser B (2010) Oxidative stress and inflammation response after nanoparticle exposure: differences between human lung cell monocultures and an advanced three-dimensional model of the human epithelial airways. J Roy Soci Inter 7:S27-S40

Muhlfeld C, Rothen-Rutishauser B, Blank F, Vanhecke D, Ochs M, Gehr P (2008) Interactions of nanoparticles with pulmonary structures and cellular responses. Am J Physiol; Lung, Cell Mol Physiol 294:L817-L829

Mühlfeld C, Gehr P, Rothen-Rutishauser B (2008) Translocation and cellular entering mechanisms of nanoparticles in the respiratory tract. Swiss Medical Weekly 138:387-391

Oberdorster G, Ferin J, Morrow PE (1992) Volumetric loading of alveolar macrophages (AM): a possible basis for diminished AM-mediated particle clearance. Exp Lung Res 18:87-104

Oberdorster G, Oberdorster E, Oberdorster J (2005) Nanotoxicology: An emerging discipline evolving from studies of ultrafine particles. Environ Health Perspec 113:823-839

Oberdorster G, Stone V, Donaldson K (2007) Toxicology of nanoparticles: a historical perspective. Nanotox 1:2-25

Park S, Lee YK, Jung M, Kim KH, Chung N, Ahn EK, Lim Y, Lee KH (2007) Cellular toxicity of various inhalable metal nanoparticles on human alveolar epithelial cells. Inhal Toxicol 19(Suppl 1):59-65

Peters A, Wichmann HE, Tuch T, Heinrich J, Heyder J (1997) Respiratory effects are associated with the number of ultrafine particles. Am J Respir Crit Care Med 155:1376-1383

Poland CA, Duffin R, Kinloch I, Maynard A, Wallace WAH, Seaton A, Stone V, Brown S, MacNee W, Donaldson K (2008) Carbon nanotubes introduced into the abdominal cavity of mice show asbestos-like pathogenicity in a pilot study. Nat Nanotech 3:423428

Pope CA, Dockery DW (1999) Epidemiology of particle effects. Air Poll Health 31:674-705

Pope CA, Ezzati M, Dockery DW (2009) Fine-particulate air pollution and life expectancy in the United States. N Eng J Med 360:376-386

Rothen-Rutishauser B, Kiama SG, Gehr P (2005) A three-dimensional cellular model of the human respiratory tract to study the interaction with particles. Am J Respir Cell Mol Biol 32:281289

Rothen-Rutishauser B, Schurch S, Gehr P (2007) Interaction of particles with membranes. In: Donaldson K, Borm P (eds) The toxicology of particles. CRC Press LCC, New York, pp 139-160

Rothen-Rutishauser B, Blank F, Ch Muehlfeld, Gehr P (2008a) In vitro models of the human epithelial airway barrier to study the toxic potential of particulate matter. Exp Opin Drug Metab Toxicol 4:1075-1089

Rothen-Rutishauser B, Müller L, Blank F, Ch Mühlfeld, Gehr P (2008b) A newly developed in vitro model of the human epithelial airway barrier to study the toxic potential of nanoparticles. ALTEX 25:191-196

Rotoli BM, Bussolati O, Bianchi MG, Barilli A, Balasubramanian C, Bellucci S, Bergamaschi E (2008) Non-functionalized multiwalled carbon nanotubes alter the paracellular permeability of human airway epithelial cells. Toxicol Lett 178:95-102

Ryman-Rasmussen JP, Cesta MF, Brody AR, Shipley-Phillips JK, Everitt JI, Tewksbury EW, Moss OR, Wong BA, Dodd DE,
Andersen ME, Bonner JC (2009) Inhaled carbon nanotubes reach the subpleural tissue in mice. Nat Nanotech 4:747-751

Schins RP, Knaapen AM (2007) Genotoxicity of poorly soluble particles. Inhal Toxicol 19:189-198

Schulz H, Harder V, Ibald-Mulli A, Khandoga A, Koenig W, Krombach F, Radykewicz R, Stampfl A, Thorand B, Peters A (2005) Cardiovascular effects of fine and ultrafine particles. J Aero Med 18:1-22

Schwartz J (2004) The effects of particulate air pollution on daily deaths: a multi-city case cross over analysis. Occ Environ Med 61:956-961

Seaton A, MacNee W, Donaldson K, Godden D (1995) Particulate air pollution and acute health effects. Lancet 345:176-178

Service RF (2004) Nanotoxicology. Nanotechnology grows up. Science 304:1732-1734

Stearns RC, Paulauskis JD, Godleski JJ (2001) Endocytosis of ultrafine particles by A549 cells. Am J Respir Cell Mol Biol 24:108-115

Stoeger T, Reinhard C, Takenaka S, Schroeppel A, Karg E, Ritter B, Heyder J, Schulz H (2006) Instillation of six different ultrafine carbon particles indicates a surface areas threshold dose for acute lung inflammation in mice. Environ Health Perspec 114:328-333

Stone V, Johnston H, Schins RPF (2009) Development of in vitro systems for nanotoxicology: methodological considerations. Crit Rev Toxicol 39:613-626

Timbrell J (1999) Principles of biochemical toxicology. Taylor and Francis, CRC Press

Tippe A, Heinzmann U, Roth C (2002) Deposition of fine and ultrafine aerosol particles during exposure at the air/cell interface. Aero Sci 33:207-218

Unfried K, Albrecht C, Klotz LO, von Mikecz A, Grether-Beck S, Schins RPF (2007) Cellular responses to nanoparticles: target structures and mechanisms. Nanotox 1:1-20

Veranth JM, Kaser EG, Veranth MM, Koch M, Yost GS (2007) Cytokine responses of human lung cells (BEAS-2B) treated with micron-sized and nanoparticles of metal oxides compared to soil dusts. Part Fibre Toxicol 4:2

Waldman WJ, Kristovich R, Knight DA, Dutta PK (2007) Inflammatory properties of iron-containing carbon nanoparticles. Chem Res Toxicol 20:1149-1154

Wichmann HE, Spix C, Tuch T, Wolke G, Peters A, Heinrich J, Kreyling WG, Heyder J (2000) Daily mortality and fine and ultrafine particles in Erfurt, Germany part I: role of particle number and particle mass. Research Report/Health Effects Institute 98:5-86

Wick P, Manser P, Limbach LK, Dettlaff-Weglikowska U, Krumreich F, Roht S, Stark WJ, Bruinink A (2007) The degree and kind of agglomeration affect carbon nanotube cytotoxicity. Toxicol Lett 168:121-131

Worle-Knirsch JM, Pulskamp K, Krug HF (2006) Oops they did it again! Carbon nanotubes hoax scientists in viability assays. Nano Lett 6:1261-1268

Wottrich R, Diabaté S, Krug HF (2004) Biological effects of ultrafine model particles in human macrophages and epithelial cells in mono- and co-culture. Int J Hyg Environ Health 207:353-361

Zanobetti A, Schwartz J, Samoli E, Gryparis A, Touloumi G, Peacock J, Anderson RH, Tertre A, Bobros J, Celko M, Goren A, Forsberg B, Michelozzi P, Rabczenko D, Perzhoyso S, Wichmann HE, Katsouyanni K (2003) The temporal pattern of respiratory and heart disease mortality in response to air pollution. Environ Health Perspec 111:118-1214 